\title{
Bottom-up or top-down: unit cost estimation of tuberculosis diagnostic tests in India
}

\author{
S. Rupert, ${ }^{*}$ A. Vassall, ${ }^{\star \dagger}$ N. Raizada ${ }^{\ddagger}$ S. D. Khaparde, ${ }^{\$}$ C. Boehme, ${ }^{\ddagger}$ V. S. Salhotra, ${ }^{\natural}$ K. S. Sachdeva, ${ }^{\$}$ \\ S. A. Nair, \# A. H. van't Hoog*,**
}

*Amsterdam Institute for Global Health and Development, Amsterdam, The Netherlands; ${ }^{\dagger}$ Social and Mathematical Epidemiology Group, Department of Global Health and Development, London School of Hygiene \& Tropical Medicine, London, UK; ${ }^{\ddagger}$ Foundation for Innovative New Diagnostics, New Delhi, ${ }^{\S}$ Central TB Division, Government of India, New Delhi, "Central TB Division, Ministry of Health and Family Welfare, New Delhi, "World Health Organization, Country Office for India, New Delhi, India; **Academic Medical Centre, University of Amsterdam, Department of Global Health, Amsterdam, The Netherlands

S U M M A R Y

SETTING: Of 18 sites that participated in an implementation study of the Xpert ${ }^{\circledR}$ MTB/RIF assay in India, we selected five microscopy centres and two reference laboratories.

OBJECTIVE: To obtain unit costs of diagnostic tests for tuberculosis (TB) and drug-resistant TB.

DESIGN : Laboratories were purposely selected to capture regional variations and different laboratory types. Both bottom-up and the top-down methods were used to estimate unit costs.

RESULTS: At the microscopy centres, mean bottom-up unit costs were respectively US\$0.83 (range US\$0.60US\$1.10) and US\$12.29 (US\$11.61-US\$12.89) for sputum smear microscopy and Xpert. At the reference laboratories, mean unit costs were US\$1.69 for the decontamination procedure, US\$9.83 for a solid culture, US\$11.06 for a liquid culture, US\$29.88 for a drug susceptibility test, and US\$18.18 for a line-probe assay. Top-down mean unit cost estimates were higher for all tests, and for sputum smear microscopy and Xpert these increased to respectively US\$1.51 and US\$13.58. The difference between bottom-up and top-down estimates was greatest for tests performed at the reference laboratories.

CONCLUSION: These unit costs for TB diagnostics can be used to estimate resource requirements and costeffectiveness in India, taking into account geographical location, laboratory type and capacity utilisation.

KEY WORDS : tuberculosis; costs; bottom-up; topdown; diagnostic tests
IMPROVED DIAGNOSTIC TESTING for tuberculosis (TB) and drug-resistant TB is one of the pillars of the global strategy to combat TB. ${ }^{1} \mathrm{New}$ tests have started to become available and are currently being implemented. ${ }^{2}$ The Xpert ${ }^{\circledR}$ MTB/RIF assay (Cepheid, Sunnyvale, CA, USA) was endorsed by the World Health Organization as a cost-effective test for the detection of TB and rifampicin (RMP) resistance. ${ }^{1}$

The scale-up of new diagnostic tests and strategies for TB and drug-resistant TB have important economic implications. ${ }^{3}$ Economic analyses to determine the cost-effectiveness, affordability or budgetimpact implications of scaling up new diagnostic tests require reliable cost estimates of diagnostic tests and procedures.

To assess the feasibility of the Xpert assay roll-out in India, an implementation study was conducted to investigate the effect on case detection under programmatic conditions and assess the cost of the roll-out. ${ }^{4,5}$ For an economic analysis of the poten- tial scale-up of Xpert testing in India, unit cost estimates of Xpert, sputum smear microscopy (SSM), as well as of other commonly used tests to diagnose drug-resistant TB in India, were required. Earlier TB diagnostic costing studies in India were from limited settings and conducted during the early stages of Xpert demonstration studies. ${ }^{6}$ Costs may differ at scale and in routine settings. ${ }^{7}$

We present the unit costs of the Xpert assay, SSM and other commonly used drug resistance tests in India across a range of geographic and laboratory settings. For scale-up purposes, costs estimated by bottom-up and top-down methods may be equally important. ${ }^{7}$ We therefore estimated costs with the bottom-up or ingredient approach and with the topdown method, and we present a full capacity costing of Xpert. These estimates, under different conditions of service volume, inform scale-up decisions of Xpert across different sites in India.

Correspondence to: Neeraj Raizada, Foundation for Innovative New Diagnostics (FIND), New Delhi, Flat No 6-14, 9th floor, Vijaya Building, 17 Barakhamba Road, New Delhi 110001, India. e-mail: Neeraj.raizada@finddx.org Article submitted 8 July 2016. Final version accepted 28 December 2016. 
Table 1 Characteristics of the laboratories included in the study

\begin{tabular}{|c|c|c|c|c|c|c|c|}
\hline & DMC \#1 & DMC \#2 & DMC \#3 & DMC \#4 & DMC \#5 & IRL \#1 & IRL \#2 \\
\hline State & Delhi & Assam & Assam & $\begin{array}{l}\text { Andhra } \\
\text { Pradesh }\end{array}$ & $\begin{array}{l}\text { Andhra } \\
\text { Pradesh }\end{array}$ & Assam & Delhi \\
\hline Urban or rural & Urban & Urban & Rural & Rural & Rural & Urban & Urban \\
\hline Type of laboratory & DMC & DMC & DMC & DMC & DMC & $\mathrm{IRL}$ & IRL \\
\hline Year of assessment & 2013-2014 & 2013-2014 & 2013-2014 & 2013-2014 & 2013-2014 & 2013-2014 & 2013-2014 \\
\hline $\begin{array}{l}\text { Population covered } \\
\text { by each laboratory } \\
\text { Persons requiring } \\
\text { diagnostic testing }\end{array}$ & 4500000 & 7804100 & 3341550 & 5956170 & 5375670 & NA & NA \\
\hline for TB in $2013, n$ & 4466 & 5803 & 1160 & 6232 & 4289 & 3775 & 10923 \\
\hline $\begin{array}{l}\text { Diagnostic tests } \\
\text { available }\end{array}$ & SSM, Xpert & SSM, Xpert & SSM, Xpert & SSM, Xpert & SSM, Xpert & $\begin{array}{l}\text { SSM, culture } \\
\text { (solid/liquid), } \\
\text { DST, LPA, } \\
\text { MTB ID }\end{array}$ & $\begin{array}{l}\text { SSM, culture } \\
\text { (solid/liquid), } \\
\text { DST, LPA, } \\
\text { MTB ID }\end{array}$ \\
\hline
\end{tabular}

$\mathrm{DMC}=$ designated microscopy centre; IRL = intermediate reference laboratory; $N A=$ not available; SSM = sputum smear microscopy; DST = drug susceptibility testing; LPA = line-probe assay; MTB ID = M. tuberculosis rapid speciation.

\section{STUDY POPULATION AND METHODS}

Setting and selection

We selected laboratories among the 18 sites that were part of the Xpert implementation study in India, located in 13 of the 29 states. ${ }^{5}$ Of the 18 sites, 13 were part of a hospital and five were located at primary health care facilities; 6 were located in urban settings, 7 in rural settings and 5 in tribal and hilly areas. To obtain representative costing estimates for TB diagnostic tests, we purposely selected five designated microscopy centres, 4 of which were located in hospitals and 1 in a primary health care facility. Besides variations in the physical location, we considered variations in workload, urban vs. rural settings, geographic distribution and proximity to intermediate reference laboratories (IRLs). The five microscopy centres selected represented an average workload of between 89 and 476 patients requiring TB testing each month. We selected 1 designated microscopy centre (DMC) in the north of India, 2 DMCs in the south and 2 in the east. Two microscopy centres were in urban and three in rural settings. To observe drug resistance tests, we selected two reference laboratories in close proximity to three of the five microscopy centres, in the north and the east, respectively. Table 1 provides an overview of the laboratory characteristics.

Ethics approval was obtained from the Institution Ethics Committee of the National Tuberculosis Institute, Bangalore, India. Approval for the study was granted by the Central TB Division, Ministry of Health and Family Welfare, Government of India, New Delhi, India.

At the DMCs, we observed the Xpert assay and Ziehl-Neelsen and auramine-stained SSM. At the IRLs, we observed solid culture on LöwensteinJensen (LJ) medium, liquid culture and drug susceptibility testing (DST) with the BACTEC ${ }^{\mathrm{TM}}$ MGIT $^{\mathrm{TM}}$ (Mycobacterium Growth Indicator Tube; BD, Sparks, MD, USA) system, the GenoType ${ }^{\circledR}$
MTBDRplus (Hain Lifescience, Nehren, Germany) line-probe assay (LPA) v. 2 and M. tuberculosis rapid speciation (MTB ID). The MGIT DST was observed for first-line drugs (i.e., RMP, ethambutol, isoniazid and streptomycin). Specimen decontamination was costed as a separate procedure. The number of observations as well as the specimen being observed was determined by the workload on the day of the observation and the days available at each laboratory. One investigator (SR) used a stopwatch to time all the activities required to perform each laboratory procedure. Observations were made in December 2013 and January 2014, when the implementation study had been running for at least 1.5 years at the selected sites.

\section{Bottom-up vs. top-down}

Our primary estimate was the cost of performing a single test, i.e., the unit cost calculated using the ingredient approach, where the measured resource use of the input is multiplied by the cost of the input. This estimate only includes directly observed resources, which is different from a top-down estimate, which takes into account total laboratory expenditures and allocates them to specific tests. The top-down method better captures underutilised resources, as it allocates total cost among all activities. For example, while in the bottom-up method the cost of the GeneXpert machine would be estimated based on inputs used to conduct one test, in the top-down method the total cost of the machine is divided by the number of tests. If the GeneXpert machine is underutilised, top-down estimates would be higher than bottom-up estimates.

\section{Bottom-up}

For each test, we measured resources used for the preparation, inoculation and incubation of the specimen, if applicable, and resources used for 
reporting the results. We collected inputs and their resources for the following categories: building, staff, equipment, reagents and chemicals, consumables and overheads. The unit of observation used for building, staff and equipment was time, for reagents and chemicals it was the volume used and for consumables it was the number of units used. We collected general information about the site, including operational minutes and building surface, using interviews and measurements. Non-observable overhead costs, such as building costs, administrative expenses and expenses incurred for utilities, were first determined through an examination of the financial records, and then through staff interviews and laboratory records. As is common in costing exercises, overhead resources were allocated to tests based on the amount of staff time or building space being used to perform the test, as measured during the observation. ${ }^{8,9}$ The prices of the equipment, drugs and medical supplies were provided by the procurement department of the Foundation for Innovative New Diagnostics India Office (New Delhi, India). Where information was not available, we consulted the United Nations Children's Fund Supply Catalogue ${ }^{10}$ and the Loba Chemie price list. ${ }^{11}$ Costs related to buildings and equipment were annualised over their expected lifetime using a standard discount rate of $3 \% .{ }^{12}$ For buildings, an expected lifetime of 30 years was used; for equipment it was set between 2 and 15 years and for furniture we used 5 years.

All unit costs were calculated in a purpose-built Excel spreadsheet (MicroSoft, Redmond, WA, USA) that was developed for TB diagnostic test costing. All locally collected costs were in Indian rupees (INR) and are converted to US dollars (USD) using the exchange rate for March 2014. ${ }^{13}$

\section{Top-down}

In the top-down method, we used expenditure data and collected figures on the number of Xpert assays and SSM tests performed annually at each microscopy centre. The top-down estimate was calculated by dividing total annual expenditures on salaries and the annual cost of buildings and equipment allocated specifically to each test by the numbers of tests performed annually. We first divided the total cost of the building space, the testing equipment (on the basis of observation) and annual staff salaries by the annual workload. We then allocated the total overhead costs per laboratory based on the building space that was used for either SSM or Xpert testing, and then also divided by the annual workload. For reagents and chemicals, and consumables, as annual expenditure data were unavailable, we used the costs as estimated in the bottom-up method.

\section{Scenario and sensitivity analyses}

To assess the effect of capacity underutilisation on unit cost for all tests, we compared bottom-up and top-down estimates. As GeneXpert machines can simultaneously run 1-4 tests, we also assessed whether underutilisation of the machine affected the bottom-up unit costs. We changed all fixed resources (i.e., building space, equipment, staff and overheads) as if used at full machine capacity of 8 (two 4-slot machines), instead of the actual observed capacity.

For solid culture, we investigated whether or not the number of specimens included in an observation session affected the unit cost. We simulated an increase in the number of specimens included in the first observation from 4 (observed) to 26 (number of specimens included in the second observation). Resource use increased proportionally.

We validated the annual maintenance cost for Xpert by comparing the value obtained from standard formulae that were applied to all tests and assume an expected lifetime, with annual maintenance costs as observed in the programme.

\section{Cost of the full diagnostic process for drug resistance}

Finally, we calculated the cost of the diagnosis of drug resistance, which requires a diagnostic algorithm, by summing the bottom-up estimates of all procedures and tests included in the algorithm.

\section{RESULTS}

A total of 32 observations were made to estimate resource use (Table 2). Using the bottom-up method, the mean unit cost for SSM was US\$0.83, ranging across observations and sites from US\$0.60 to US\$1.10. Using the top-down method, the mean unit cost for SSM was higher, US\$1.51 (range US\$0.63US\$1.84). The mean unit cost for the Xpert assay was US\$12.29 (range US\$11.61-US\$12.89) using the bottom-up method and increased to US\$13.58 (range US\$11.98-US\$16.43) when applying the top-down method. The mean unit cost per test at reference laboratories was US\$1.69 for the decontamination procedure, US\$9.83 for a solid culture test, US\$11.06 for a liquid culture test, US\$29.88 for DST, US\$18.18 for an LPA and US\$3.95 for an MTB ID test with the bottom-up method; these also increased for all tests when using the top-down method.

When the GeneXpert machines were used at full capacity, the bottom-up unit cost fell by $6 \%$ to US\$11.58. The bottom-up cost estimate of a solid culture varied between US\$2.29 and US\$17.83, depending on the number of specimens included in the observation session. Simulating the inclusion of a larger number of specimens reduced the unit cost from US\$17.83 to US\$3.39. The decrease was 
Table 2 Number of annual tests, observations per test, specimen per test and unit costs per test*

\begin{tabular}{|c|c|c|c|c|c|c|}
\hline Test & Site(s) & Method & $\begin{array}{l}\text { Mean annual } \\
\text { number of tests } \\
\text { (min-max) }\end{array}$ & $\begin{array}{l}\text { Number of } \\
\text { observations }\end{array}$ & $\begin{array}{l}\text { Mean number of } \\
\text { specimen per } \\
\text { observations } \\
\text { (min-max) }\end{array}$ & $\begin{array}{l}\text { Mean unit cost } \\
\quad(\min -\max )\end{array}$ \\
\hline \multirow[t]{2}{*}{ SSM: ZN } & \multirow[t]{2}{*}{ All 5 DMCs } & Top-down & $8780(2320-12464)^{\dagger}$ & $N A^{2}$ & NA & $1.44(0.63-1.84)$ \\
\hline & & Bottom-up & NA & 7 & $11.43(6-24)$ & $0.85(0.6-1.1)$ \\
\hline \multirow{2}{*}{ SSM: auramine } & \multirow{2}{*}{$\begin{array}{c}\text { All } 5 \text { DMCs } \\
+ \text { IRL \#2 }\end{array}$} & Top-down & 15389 (4 811-21 846) & NA & NA & $1.89(1.75-2.13)$ \\
\hline & & Bottom-up & NA & 3 & $14(7-25)$ & $0.84(0.67-1.01)$ \\
\hline \multirow[t]{3}{*}{ Xpert } & \multirow[t]{3}{*}{ All 5 DMCs } & Top-down & 4336 (1 384-5 966) & NA & NA & $13.58(11.97-16.43)$ \\
\hline & & Bottom-up & NA & 6 & $4.83(2-7)$ & $12.29(11.61-12.89)$ \\
\hline & & Full capacity & NA & 6 & NA & $11.58(10.7-12.72)$ \\
\hline \multirow[t]{2}{*}{ Decontamination } & \multirow[t]{2}{*}{ Both IRLs } & Top-down & 11805 (6 330-17 280) & NA & NA & $3.38(2.97-4.45)$ \\
\hline & & Bottom-up & NA & 4 & $15(9-20)$ & $1.69(0.98-2.3)$ \\
\hline \multirow[t]{2}{*}{ Solid culture } & \multirow[t]{2}{*}{ Both IRLs } & Top-down & 4453 (2 661-6 245) & NA & NA & $10.94(7.35-13.16)$ \\
\hline & & Bottom-up & NA & 3 & $12.67(4-26)$ & $9.83(2.29-17.83)$ \\
\hline \multirow[t]{2}{*}{ Liquid culture } & \multirow[t]{2}{*}{ Both IRLs } & Top-down & 3747 (1 618-5 875) & NA & NA & $15.95(10.11-21.79)$ \\
\hline & & Bottom-up & NA & 2 & $17(16-18)$ & $11.06(9.01-13.12)$ \\
\hline \multirow[t]{2}{*}{ DST } & \multirow[t]{2}{*}{ IRL \#2 } & Top-down & 72 & NA & NA & $546.76(546.22-547.3)$ \\
\hline & & Bottom-up & NA & 2 & $3(2-4)$ & $29.88(26.34-33.42)$ \\
\hline \multirow[t]{2}{*}{ LPA } & \multirow[t]{2}{*}{ Both IRLS } & Top-down & 3565 (2 042-5 088) & NA & NA & $33.75(28.13-39.37)$ \\
\hline & & Bottom-up & NA & 2 & $17(14-20)$ & $18.18(17.09-19.27)$ \\
\hline \multirow[t]{2}{*}{ MTB ID } & \multirow[t]{2}{*}{ Both IRLS } & Top-down & Unobtainable ${ }^{3}$ & Unobtainable & Unobtainable & - \\
\hline & & Bottom-up & NA & 2 & $1(1-1)$ & $3.95(3.74-4.16)$ \\
\hline
\end{tabular}

* Only data on total microscopy tests were recorded; no distinction was made between ZN and auramine staining.

'Except for 'reagents and chemicals and consumables', for which we used the bottom-up method to calculate costs.

${ }^{\ddagger}$ We were not able to estimate the unit cost with the top-down method as figures on total annual number of tests performed were not known at the time of data collection.

SSM = sputum smear microscopy; ZN = Ziehl-Neelsen; DMC = designated microscopy centre; $N A=$ not applicable; IRL=intermediate reference laboratory; DST = drug susceptibility testing; LPA = line-probe assay; MTB ID = M. tuberculosis rapid speciation.

primarily caused by a drop in building costs, of approximately US $\$ 10$. In the top-down method, the same simulation reduced unit costs by $2 \%$.

SSM reagents and chemicals comprised on average $36 \%$ of the mean bottom-up unit cost, followed by consumables $(30 \%)$ and overheads $(21 \%)$ (Table 3). The composition of the unit cost changed when the top-down method was used, and overhead costs comprised on average $40 \%$ of the unit cost, while reagents and chemicals comprised $20 \%$. Regardless of the method used, the cost per Xpert assay was primarily determined by the cost of the cartridge (US\$9.98), included in the component reagents and chemicals, and comprised on average $85 \%$ of the total unit costs (Table 4). The cost categories for DST and other TB tests and proce-

Table 3 Mean costs per sputum smear microscopy test in designated microscopy centres (in 2014 USD)

\begin{tabular}{|c|c|c|c|c|c|c|c|c|c|c|c|}
\hline \multirow{2}{*}{$\begin{array}{l}\text { Number of } \\
\text { specimens } \\
\text { observed }\end{array}$} & \multicolumn{3}{|c|}{ Site \#1 } & \multirow{2}{*}{$\frac{\frac{\text { Site \#2 }}{\text { ZN }}}{(n=6)}$} & \multirow{2}{*}{ 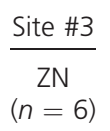 } & \multicolumn{3}{|c|}{ Site \#4 } & \multirow{2}{*}{$\begin{array}{c}\text { Site \#5 } \\
\text { ZN } \\
(n=23)\end{array}$} & \multirow[b]{2}{*}{$\begin{array}{l}\text { Mean cost across } \\
\text { observations (range) }\end{array}$} & \multirow{2}{*}{$\begin{array}{c}\text { Proportion } \\
\text { of total } \\
\%\end{array}$} \\
\hline & $\begin{array}{c}\text { Auramine } \\
(n=7)\end{array}$ & $\begin{array}{c}\text { Auramine } \\
(n=10)\end{array}$ & $\begin{array}{c}\mathrm{ZN} \\
(n=6)\end{array}$ & & & $\begin{array}{c}\mathrm{ZN} \\
(n=24)\end{array}$ & $\begin{array}{c}\mathrm{ZN} \\
(n=7)\end{array}$ & $\begin{array}{c}\mathrm{ZN} \\
(n=8)\end{array}$ & & & \\
\hline \multicolumn{12}{|l|}{ Bottom-up method } \\
\hline Overhead & 0.288 & 0.211 & 0.253 & 0.408 & 0.13 & 0.088 & 0.088 & 0.083 & 0.03 & $0.18(0.03-0.408)$ & 21.2 \\
\hline Building space & 0.098 & 0.041 & 0.044 & 0.025 & 0.003 & 0.035 & 0.039 & 0.034 & 0.008 & $0.04(0.003-0.098)$ & 4.4 \\
\hline Equipment & 0.002 & 0.002 & 0.003 & 0.011 & 0.003 & 0.004 & 0.003 & 0.003 & 0.004 & $0.004(0.002-0.011)$ & 0.5 \\
\hline Staff & 0.053 & 0.042 & 0.05 & 0.036 & 0.019 & 0.108 & 0.104 & 0.101 & 0.059 & $0.06(0.019-0.108)$ & 7.7 \\
\hline $\begin{array}{l}\text { Reagents and } \\
\text { chemicals }\end{array}$ & 0.086 & 0.086 & 0.235 & 0.135 & 0.285 & 0.496 & 0.490 & 0.571 & 0.309 & $0.3(0.086-0.571)$ & 36.1 \\
\hline Consumables & 0.327 & 0.285 & 0.215 & 0.088 & 0.327 & 0.192 & 0.321 & 0.303 & 0.185 & $0.25(0.088-0.327)$ & 30.1 \\
\hline Total & 0.85 & 0.67 & 0.8 & 0.7 & 0.77 & 0.92 & 1.04 & 1.1 & 0.6 & $0.83(0.6-1.1)$ & 100 \\
\hline \multicolumn{12}{|l|}{ Top-down method } \\
\hline Overhead & 0.951 & 0.951 & 0.951 & 0.278 & 0.83 & 0.435 & 0.435 & 0.435 & 0.153 & $0.6(0.153-0.951)$ & 39.8 \\
\hline Building space & .138 & 0.138 & 0.138 & 0.055 & 0.015 & 0.068 & 0.068 & 0.068 & 0.067 & $0.08(0.015-0.138)$ & 5.5 \\
\hline Equipment & 0.027 & 0.027 & 0.027 & 0.027 & 0.128 & 0.019 & 0.019 & 0.019 & 0.035 & $0.04(0.019-0.128)$ & 2.4 \\
\hline Staff & 0.261 & 0.261 & 0.261 & 0.05 & 0.251 & 0.281 & 0.281 & 0.281 & 0.238 & $0.24(0.05-0.281)$ & 15.9 \\
\hline $\begin{array}{l}\text { Reagents and } \\
\text { chemicals }\end{array}$ & 0.086 & 0.086 & 0.235 & 0.135 & 0.285 & 0.496 & 0.49 & 0.571 & 0.309 & $0.3(0.086-0.571)$ & 19.8 \\
\hline Consumables & 0.327 & 0.285 & 0.215 & 0.088 & 0.327 & 0.192 & 0.321 & 0.303 & 0.185 & $0.25(0.088-0.327)$ & 16.5 \\
\hline Total & 1.79 & 1.75 & 1.83 & 0.63 & 1.84 & 1.49 & 1.61 & 1.68 & 0.99 & $1.51(0.63-1.84)$ & 100 \\
\hline
\end{tabular}

ZN $=$ Ziehl-Neelsen 
Table 4 Mean costs per Xpert ${ }^{\circledR}$ MTB/RIF test in designated microscopy centres for all three methods (in 2014 USD)

\begin{tabular}{|c|c|c|c|c|c|c|c|c|}
\hline $\begin{array}{l}\text { Number of specimens } \\
\text { observed }\end{array}$ & $\begin{array}{l}\text { Site \#1 } \\
(n=7)\end{array}$ & $\begin{array}{l}\text { Site \#2 } \\
(n=10)\end{array}$ & $\begin{array}{l}\text { Site \#3 } \\
(n=6)\end{array}$ & \multicolumn{2}{|c|}{$\begin{array}{l}\text { Site \#4 } \\
(n=6)\end{array}$} & $\begin{array}{l}\text { Site \#5 } \\
(n=24)\end{array}$ & $\begin{array}{l}\text { Mean cost across } \\
\text { observations (range) }\end{array}$ & $\begin{array}{c}\text { Proportion } \\
\text { of total } \\
\%\end{array}$ \\
\hline \multicolumn{9}{|l|}{ Ingredient method } \\
\hline Overhead & 0.508 & 0.540 & 0.172 & 0.162 & 0.160 & 0.036 & $0.26(0.036-0.54)$ & 2.1 \\
\hline Building space & 0.036 & 0.021 & 0.002 & 0.071 & 0.073 & 0.005 & $0.03(0.002-0.073)$ & 0.3 \\
\hline Equipment & 1.029 & 1.896 & 1.254 & 1.060 & 1.077 & 1.241 & $1.26(1.029-1.896)$ & 10.2 \\
\hline Staff & 0.085 & 0.045 & 0.019 & 0.042 & 0.040 & 0.044 & $0.05(0.019-0.085)$ & 0.4 \\
\hline Reagents and chemicals & 9.980 & 9.980 & 9.980 & 11.368 & 11.368 & 9.980 & $10.44(9.98-11.368)$ & 85 \\
\hline Consumables & 0.273 & 0.096 & 0.464 & 0.169 & 0.169 & 0.307 & $0.25(0.096-0.464)$ & 2 \\
\hline Total & 11.911 & 12.578 & 11.891 & 12.872 & 12.887 & 11.613 & $12.29(11.61-12.89)$ & 100 \\
\hline \multicolumn{9}{|l|}{ Bottom-up method } \\
\hline Overhead & 2.017 & 0.836 & 2.074 & 0.379 & 0.379 & 0.270 & $0.99(0.27-2.074)$ & 7.3 \\
\hline Building space & 0.440 & 0.153 & 0.063 & 0.181 & 0.181 & 0.118 & $0.19(0.063-0.44)$ & 1.4 \\
\hline Equipment & 0.950 & 0.807 & 3.424 & 0.766 & 0.766 & 1.179 & $1.32(0.766-3.424)$ & 9.7 \\
\hline Staff & 0.485 & 0.103 & 0.421 & 0.391 & 0.391 & 0.602 & $0.4(0.103-0.602)$ & 2.9 \\
\hline Reagents and chemicals & 9.980 & 9.980 & 9.980 & 11.368 & 11.368 & 9.980 & $10.44(9.98-11.368)$ & 76.9 \\
\hline Consumables & 0.273 & 0.096 & 0.464 & 0.169 & 0.169 & 0.307 & $0.25(0.096-0.464)$ & 1.8 \\
\hline Total & 14.145 & 11.975 & 16.426 & 13.254 & 13.254 & 12.456 & $13.58(11.97-16.43)$ & 100 \\
\hline \multicolumn{9}{|l|}{ Full capacity method } \\
\hline Overhead & 0.254 & 0.135 & 0.064 & 0.142 & 0.140 & 0.027 & $0.13(0.027-0.254)$ & 1.1 \\
\hline Building space & 0.018 & 0.005 & 0.001 & 0.062 & 0.064 & 0.004 & $0.03(0.001-0.064)$ & 0.22 \\
\hline Equipment & 0.515 & 0.474 & 0.470 & 0.927 & 0.942 & 0.931 & $0.71(0.47-0.942)$ & 6.13 \\
\hline Staff & 0.042 & 0.011 & 0.007 & 0.037 & 0.035 & 0.033 & $0.03(0.007-0.042)$ & 0.24 \\
\hline Reagents and chemicals & 9.980 & 9.980 & 9.980 & 11.368 & 11.368 & 9.980 & $10.44(9.98-11.368)$ & 90.19 \\
\hline Consumables & 0.273 & 0.096 & 0.464 & 0.169 & 0.169 & 0.307 & $0.25(0.096-0.464)$ & 2.13 \\
\hline Total & 11.082 & 10.701 & 10.987 & 12.704 & 12.717 & 11.281 & $11.58(10.7-12.72)$ & 100 \\
\hline
\end{tabular}

dures performed at the IRLs are presented in the Appendix. ${ }^{1}$

Substituting the annual maintenance costs of the GeneXpert machine calculated using the formulae with observed annual maintenance costs minimally increased the average unit costs for the Xpert assay by respectively $1.7 \%$ and $1.6 \%$ in the bottom-up and top-down methods.

The average cost of obtaining a DST profile on a sample would be equal to US\$42.65, if we add the unit cost of decontamination, liquid culture and DST. The cost of a full procedure to perform an LPA was US $\$ 20.89$, if the costs of decontamination, direct SSM and LPA are combined.

\section{DISCUSSION}

On comparing our findings for the SSM and Xpert assay with previous results from the demonstration study in India from 2010, ${ }^{6}$ we found that the cost of Xpert was lower, primarily due to the reduced price for Xpert reagents. ${ }^{14}$ In addition, cost estimates for equipment and staff cost components were lower in our study, possibly due to economies of scale, as we costed larger sites. Our unit costs for liquid culture, DST and Xpert were similar to those found in a South African study. ${ }^{15}$ Unit costs for SSM were considerably lower than found in South Africa, explained by the

\footnotetext{
${ }^{1}$ The appendix is available in the online version of this article, at http://www.ingentaconnect.com/content/iuatld/ijtld/2017/ 00000021/00000004/art00005
}

higher labour costs there, which comprise a large percentage of SSM unit cost. We also found lower costs for Xpert than those reported in South Africa, due to differences in prices of non-tradable goods (such as salaries) and the fact that we were estimating costs at full implementation rather than during scale-up. ${ }^{7}$

Bottom-up unit cost estimates for SSM and Xpert varied between sites, mostly due to differences in the use of reagents, chemicals and consumables. Fixed costs, such as building costs, did not vary substantially between settings. Variations in overhead costs were primarily related to costs of management staff. Variations in overheads may also have been due to the extent of staff time, as this increases the amount of total overhead costs that are then allocated to SSM. Differences in the cost of consumables by site were primarily explained by some staff not wearing laboratory coats, which is not advised.

For solid and liquid culture, and DST, building costs comprised a large proportion of unit costs. The need for a long incubation period in laboratories with advanced biosafety requirements increased the costs of utilisation of laboratory space and time in reference laboratories compared to microscopy centres. Both bottom-up unit costs and top-down costs were sensitive to the number of specimens tested per batch. In the top-down method, a change in the number of specimens per batch affected the unit cost, as some of the costs were allocated by dividing the estimated annual building cost by the annual number of tests performed. High costs for buildings also explained the cost difference between direct SSM 
(US\$1.01) at the microscopy centres and SSM performed on liquid culture isolates at the reference laboratories (US\$7.70). For DST, top-down cost estimates were much higher than the bottom-up approach because the use of DST $(n=72)$ was low compared to the other tests, suggesting a high level of excess capacity in DST resourcing.

Not surprisingly, we generally found top-down costs to be higher than bottom-up costs. There was one exception, likely due to measurement bias by the staff when using a bottom-up method. In this case, some staff may take longer to perform a test than usual. The top-down method increased the mean unit cost across sites for SSM by $80 \%$ and for the Xpert assay by $11 \%$ compared to the bottom-up method. This suggests underutilisation of current diagnostic capacity. The smaller proportional difference for the Xpert assay is because a higher proportion of the cost of Xpert is due to items such as consumables, where 'excess capacity' is unlikely to occur. This difference in top-down and bottom-up costs therefore suggests that further scale-up of interventions could lead to improvements in efficiency and cost reductions, ${ }^{7}$ as capacity in resources such as building and staff become better utilised. A scale-up may also enhance the knowledge of staff, which could lead to improved efficiency in processes, and possibly task shifting to more junior staff over time, which may also further reduce costs.

In conclusion, we obtained unit costs for $\mathrm{TB}$ diagnostics across different settings in India, taking into account geographical location, laboratory type and capacity utilisation. These costs suggest room for further efficiencies and provide an essential base for estimating resource requirements and the costeffectiveness of Xpert roll-out in India.

\section{Acknowledgements}

The authors would like to thank the site coordinators of the designated microscopy centres and the persons in charge of the intermediate reference laboratories for their assistance and cooperativeness in collecting the data. We would also like to thank all the friendly and helpful laboratory staff for letting us observe their work.

The study was funded by the Foundation for Innovative New Diagnostics (FIND; Geneva, Switzerland) and by the Amsterdam Institute for Global Health and Development (Amsterdam, The Netherlands)

Competing interests: The authors declare that NR and CB are employed by FIND, a non-profit organisation that collaborates with industry partners, including Cepheid Inc, in the development and evaluation of new diagnostic tests. These partners with whom we have partnered have in no way contributed to the study and would not be benefited by the results of the study. As such, there is no conflict of interest to the publication of this article. No other conflicts declared.

Spreadsheet: The Excel spreadsheet used to calculate the unit costs is available upon request from the corresponding author: s. rupert@aighd.org.

\section{References}

1 World Health Organization Global TB Programme. Automated real-time nucleic acid amplification technology for rapid and simultaneous detection of tuberculosis and rifampicin resistance: Xpert MTB/RIF assay for the diagnosis of pulmonary and extrapulmonary $\mathrm{TB}$ in adults and children. WHO/HTM/TB/2013.16. Geneva, Switzerland: WHO, 2014.

2 UNITAID. Tuberculosis diagnostics technology and market landscape. Report No. 3. Geneva, Switzerland: UNITAID, 2014: p 97. http://www.unitaid.eu/images/marketdynamics/ publications/UNITAID_TB_Diagnostics_Landscape_3rdedition.pdf Accessed January 2017.

3 Pantoja A, Fitzpatrick C, Vassall A, Weyer K, Floyd K. Xpert MTB/RIF for diagnosis of tuberculosis and drug-resistant tuberculosis: a cost and affordability analysis. Eur Respir J 2013; 42: 708-720.

4 Raizada N, Sachdeva K S, Sreenivas A, et al. Feasibility of decentralised deployment of Xpert MTB/RIF test at lower level of health system in India. PLOS ONE 2014; 9: e89301.

5 Sachdeva K S, Raizada N, Sreenivas A, et al. Use of Xpert MTB/ RIF in decentralized public health settings and its effect on pulmonary TB and DR-TB case finding in India. PLOS ONE 2015; 10: $\mathrm{e} 0126065$.

6 Vassall A, van Kampen S, Sohn H, et al. Rapid diagnosis of tuberculosis with the Xpert MTB/RIF assay in high burden countries: a cost-effectiveness analysis. PLOS MED 2011; 8: e1001120.

7 Cunnama L, Sinanovic E, Ramma L, et al. Using top-down and bottom-up costing approaches in LMICs: the case for using both to assess the incremental costs of new technologies at scale: top-down and bottom-up costing approaches in LMICs. Health Econ 2016; 25 (Suppl 1): 53-66.

8 World Health Organization. Cost analysis in primary health care: a training manual for programme managers. Geneva, Switzerland: WHO, 1994.

9 UNAIDS. Manual for costing HIV facilities and services. Geneva, Switzerland: UNAIDS, 2011. http: //www.unaids.org/ sites/default/files/en/media/unaids/contentassets/documents/ document/2011/20110523_manual_costing_HIV_facilities_en. pdf Accessed January 2017.

10 United Nations Children's Fund. The UNICEF Supply Catalogue. New York, NY, USA: UNICEF, 2014. https:// supply.unicef.org Accessed January 2017.

11 Loba Chemie. Loba Chemie Pricelist. Mumbai, India: Loba Chemie, 2014 http://www.lobachemie.com/contactus/requestcatalogue.aspx Accessed January 2017.

12 World Health Organization. Making choices in health: WHO guide to cost-effectiveness analysis. Geneva, Switzerland: WHO, 2003.

13 International Monetary Fund. Exchange rate archives by month. Washington DC, USA: IMF, 2014. https: //www.imf. org/external/np/fin/data/param_rms_mth.aspx Accessed January 2017.

14 Foundation for Innovative New Diagnostics. Price for Xpert ${ }^{\circledR}$ MTB/RIF and FIND country list. Geneva, Switzerland: FIND, 2015. http://www.finddiagnostics.org/about/what_we_do/ successes/find-negotiated-prices/xpert_mtb_rif.html Accessed January 2017.

15 Shah M, Chihota V, Coetzee G, Churchyard G, Dorman S E. Comparison of laboratory costs of rapid molecular tests and conventional diagnostics for detection of tuberculosis and drugresistant tuberculosis in South Africa. BMC Infect Dis 2013; 13: 352. 


\section{APPENDIX}

Table A.1 Cost per test in IRL\#1 (in 2014 USD)

\begin{tabular}{|c|c|c|c|c|c|c|}
\hline Number of specimens observed & $\begin{array}{l}\text { Decontamination } \\
\qquad(n=9)\end{array}$ & $\begin{array}{c}\text { Culture: solid } \\
(n=4)\end{array}$ & $\begin{array}{l}\text { Culture: solid } \\
\quad(n=8)\end{array}$ & $\begin{array}{l}\text { Culture: liquid } \\
\quad(n=16)\end{array}$ & $\begin{array}{c}\text { LPA } \\
(n=14)\end{array}$ & $\begin{array}{l}\text { MTB ID } \\
(n=1)\end{array}$ \\
\hline \multicolumn{7}{|l|}{ Bottom-up method } \\
\hline Overhead & 0.201 & 1.658 & 0.890 & 0.478 & 0.853 & 0.101 \\
\hline Building space & 0.506 & 11.925 & 6.004 & 9.064 & 0.042 & 1.090 \\
\hline Equipment & 0.219 & 3.371 & 1.701 & 0.457 & 1.274 & 0.528 \\
\hline Staff & 0.105 & 0.095 & 0.109 & 0.067 & 1.150 & 0.055 \\
\hline Reagents and chemicals & 0.662 & 0.446 & 0.456 & 0.433 & 13.382 & 1.400 \\
\hline Consumables & 0.603 & 0.337 & 0.225 & 2.616 & 2.567 & 0.564 \\
\hline Total & 2.296 & 17.832 & 9.385 & 13.115 & 19.268 & 3.738 \\
\hline \multicolumn{7}{|l|}{ Top-down method } \\
\hline Overhead & 0.952 & 4.858 & 4.858 & 4.858 & 4.123 & NA \\
\hline Building space & 0.970 & 3.654 & 3.654 & 3.796 & 5.889 & NA \\
\hline Equipment & 0.802 & 1.907 & 1.156 & 6.859 & 4.481 & NA \\
\hline Staff & 0.460 & 1.962 & 1.962 & 3.227 & 8.931 & NA \\
\hline Reagents and chemicals & 0.662 & 0.446 & 0.456 & 0.433 & 13.382 & - \\
\hline Consumables & 0.603 & 0.337 & 0.225 & 2.616 & 2.567 & - \\
\hline Total & 4.449 & 13.165 & 12.311 & 21.789 & 39.374 & NA \\
\hline
\end{tabular}

$\mathrm{IRL}=$ intermediate reference laboratory; $\mathrm{LPA}=$ line-probe assay; MTB ID $=$ M. tuberculosis rapid speciation; NA = not applicable. 


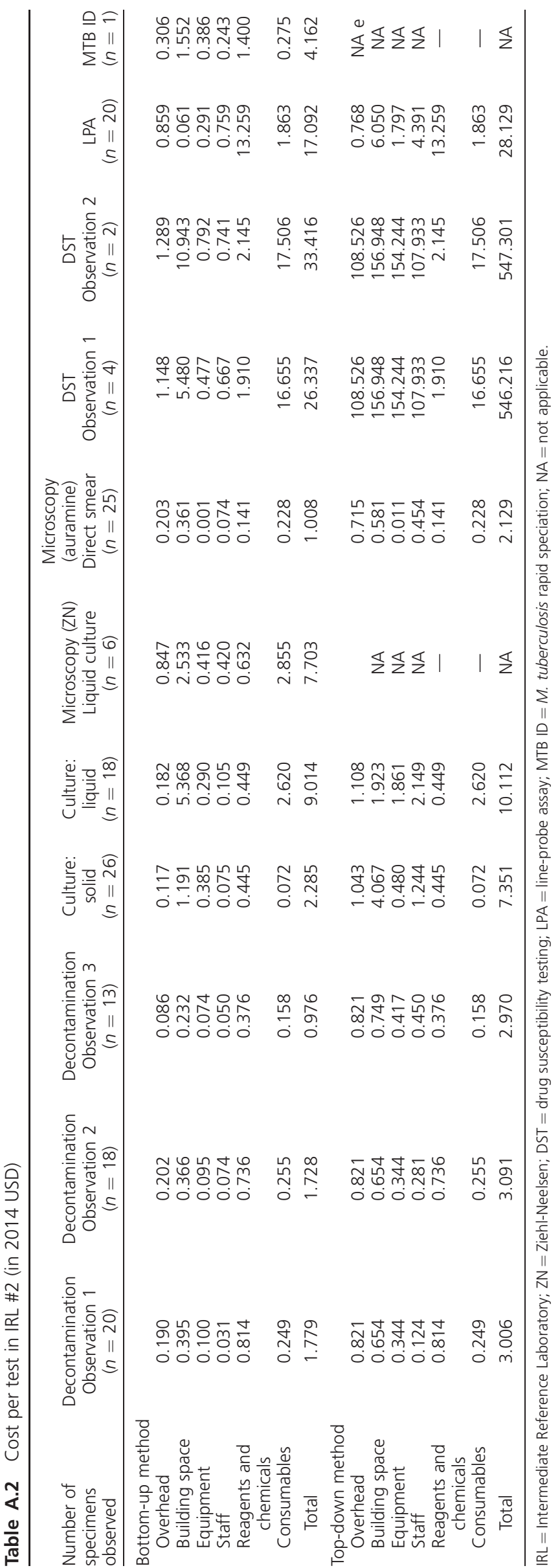


CONTEXte : Parmi les 18 sites qui ont participé à une étude de mise en œuvre du test Xpert ${ }^{\circledR}$ MTB/RIF en Inde, nous avons sélectionné cinq centres de microscopie et deux laboratoires de référence.

OBJECTIF : Obtenir les coûts unitaires des tests de diagnostic de la tuberculose (TB) et de la TB pharmacorésistante.

SCHÉ M A : Les laboratoires ont été sélectionnés de façon à être représentatifs des variations régionales et des différents types de laboratoire. Des méthodes ascendantes et descendantes ont été utilisées afin de calculer les coûts par unité.

RÉ SULTATS : Dans les centres de microscopie, les coûts unitaires moyens ascendants ont été de US\$0,83 (fourchette US\$0,60-US\$1,10) et de US\$12,29 (US\$11,61-US\$12,89) pour le frottis de crachats et l'Xpert, respectivement. Dans les laboratoires de référence, les coûts unitaires moyens ont été de US $\$ 1,69$ pour la procédure de contamination, de US\$9,83 pour la culture en milieu solide, de US\$11,06 pour la culture en milieu liquide, de US\$29,88 pour un test de pharmacosensibilité et de US\$18,18 pour un test de sonde en ligne. Les estimations des coûts unitaires moyens descendants ont été plus élevées pour tous les tests et pour le frottis de crachats et l'Xpert ont augmenté à US\$1,51 et à US\$13,58, respectivement. Les différences entre les estimations ascendantes et descendantes ont été les plus importantes pour les tests réalisés dans les laboratoires de référence.

CONCLUSION : Ces coûts unitaires du diagnostic de la TB peuvent être utilisés pour estimer les besoins en ressources et la rentabilité en Inde, en tenant compte de la localisation géographique, de type de laboratoire et de sa capacité d'utilisation.
MARCO DE REFERENCIA: De los 18 centros que participaron en un estudio de aplicación de la prueba Xpert $^{\circledR}$ MTB/RIF en la India, se escogieron cinco centros de microscopia y dos laboratorios de referencia. OBJETIV O: Conocer los costos unitarios de las pruebas diagnósticas de la tuberculosis (TB) y la TB farmacorresistente.

MÉTODO: Se practicó un muestreo intencional con el fin de captar las diferencias en las regiones y en los diversos tipos de laboratorios. La estimación de los costos unitarios se obtuvo mediante métodos de cálculo descendente y ascendente.

RESULTADOS: En los centros de microscopia, las estimaciones ascendentes revelaron un costo unitario promedio de la baciloscopia del esputo de US\$0,83 (entre US\$0,60 y US\$1,10) y de la prueba Xpert de US\$12,29 (entre US\$11,61 y US\$12,89). En los laboratorios de referencia el promedio de los costos unitarios fueron US\$1,69 por procedimiento de descontaminación US\$1,69; US\$9,83 por cultivo en medio sólido; US\$11,06 por cultivo en medio líquido; US\$29,88 por prueba de sensibilidad a los medicamentos; y US\$18,18 por cada prueba molecular con sondas en línea. Las estimaciones descendentes revelaron un costo unitario promedio más alto para todas las pruebas, pues el costo de la baciloscopia del esputo aumentó a US\$1,51 y el costo de la prueba Xpert a US\$13,58. Las diferencias entre las estimaciones ascendentes y descendentes fueron más grandes con las pruebas realizadas en los laboratorios de referencia. CONCLUSIÓN: Estos costos unitarios de las pruebas diagnósticas de la TB se pueden utilizar con el fin de calcular la necesidad de recursos y la relación de costoefectividad de las intervenciones en la India, teniendo en cuenta la ubicación geográfica, el tipo de laboratorio y la utilización de las capacidades existentes. 